\title{
第30回 群馬放射線腫瘍研究会抄録
}

\section{一般演題(1)}

座長 町田 貴志（群馬県立がんセンター）

1. ベンディングマグネット交換後のデータの検討

山田 昌巳, 氏田 浩一, 宮澤 康志

松原 國夫

（群馬大医・附属病院・放射線部）

【目的】当施設に 1991 年導入された MEVATRON 74DX は，昨年 10 月ベンディングマグネット部の水漏れ によって加速管を下ろすことを含めた同部の交換を余儀 なくされた，今回，その前後でのデータの比較検討を 行った.

【方 法】校正された Farmer 形電離箱線量計と $20 \mathrm{~cm}$ 深まで測定可能な水ファントムを用いて TPRを得, データの解析を行った。

【結 果】 $6 \mathrm{MV}-\mathrm{X}$ 線においては，旧デー夕と遜色なく 一致した．また，10MV-X 線においてはエネルギーの変 化が認められ, $5 \times 5,10 \times 10$ の照射野で深くなるに従っ て差が生じ，通常の計算点ではない $17 \mathrm{~cm}$ 深で $2 \%$ の違 いが生じた。

【結 語】放射線治療における線量投与の不確定度を土 $5 \%$ と考光た時，ファントム照射に战りる出力線量評価 は土2.5\%を達成する必要がある. 今回のデー夕は条件を 満たしていると考えるが，今後も定期的に測定し管理し ていきたい.

\section{2.フィルム法による線量測定の基礎的検討}

宮田 治郎, 宇梶 智人, 小林みちる

関根 一正（伊勢崎市民病院中央放射線科）

塩島 和美

(同放射線科)

【目的】フィルム法による線量測定の精度を検証し， (濃度一線量変換テーブル) 作成パラメータが及ぼす影 響を検討する。

【方 法】フィルムには EDR2 を, 解析ソフトには DD -System を使用し，TMR，PDD，OCR 4MV-X 線， $10 \mathrm{MV}-\mathrm{X}$ 線にて測定した. TMR は，X 線ビームに対し

\author{
日 時：平成 16 年 2 月 14 日 (土), 午後 1 時 6 時 \\ 場 所：群馬大学医学部 臨床大講堂 \\ 大会長：長谷川正俊（群馬大院・医・腫瘍放射線学）
}

フィルム面を垂直とし，PDD は，フィルム面を平行にし てファントムに挟み込み, OCR は, フィルム面ビーム垂 直と平行の双方で測定し, 電離箱線量計と比較した. 変 換テーブルは，その基準深をそれぞれ $5 \mathrm{~cm}, 10 \mathrm{~cm}$ として 作成した.

【結 果】 TMR は平均 $\pm 2.5 \%, \mathrm{PDD}$ は深度が増すほど 漸増し $20 \mathrm{~cm}$ 深で $8 \%$ を超えた. OCR は基準深近傍で一 致性が良好であったが，低エネルギー成分の影響がある と思われる深部ではやや不良であった。

\section{3. 放射線治療後直腸胵瘻を呈した子宮頸癌 2 例におけ} る 3 次元的線量評価

$\begin{array}{llll}\text { 加藤 } & \text { 弘之, 野中 哲生, 樋口 } & \text { 啓子 } \\ \text { 玉木 } & \text { 義雄 } & \text { (群馬がんセンター放射線科) } \\ \text { 西村 } & \text { 俊信, 塚越 俊夫 } & \text { (同婦人科) } \\ \text { 町田 } & \text { 貴志, 相澤健太郎, 樋口 } & \text { 雅則 } \\ \text { 遠藤 } & \text { 廣 } & & \text { (同放射線第二課) }\end{array}$

【目的】当院では子宮頸癌の低線量率腔内照射におい て, 正確な線量評価を行うために CT 画像上に線量分布 を重ねて評価を行っている. 今回, 放射線治療後に直腸 腟瘻を呈した 2 症例を経験したので, その線量評価を再 度検討し報告する。

【症 例】 84 墄, T1bN0M0, I B 期. 2001 年 8 月より放 射線治療開始, 低線量率腔内照射を 3 回行った. 2004 年 1 月に直腸胵瘻が認められた. 50 歳, T3bN1M0, III B 期. 2002 年 10 月より放射線治療開始，低線量率腔内照射を 3 回行った. 2003 年 10 月に直腸胵瘻が認められた.

【方 法】線源座標は orthogonal 法で取得し, 治療計画 装置 (CMS 社製 FOCUS) を用いて, CT 画像上に線量分 布を合成し評価を行った。

【結 果】 DVHで，A点線量以上の線量が照射された 直腸体積はそれぞれ $6 \mathrm{ml}, 3 \mathrm{ml}$ であった.

【結 語】 3 次元的線量評価は, 有害事象の発生を予測 する上で有用と思われる。 


\section{一般演題(2)}

座長 斉藤 吉弘（埼玉県立がんセンター）

\subsection{6ch MDCT による食道癌リンパ節転移の診断}

原口万須美, 堀越 浩幸, 加藤 弘之

野中 哲生, 樋口 啓子, 玉木 義雄

(群馬県立がんセンター放射線科)

【目的】食道癌リンパ節転移の診断に打いて $16 \mathrm{ch}$ MDCT 水平断像, 冠状断像による多方向からの観察の有 用性の検討を行った.

【対象と方法】食道癌手術施行例のうち, 16chMDCT を 施行した 5 症例の郭清リンパ節 448 結節を対象とした. $16 \mathrm{ch}$ MDCT を施行し, $2 \mathrm{~mm}$ 厚水平断像, 冠状断 MPR 像を用いてリンパ節の描出能, 大きさ (長径・短径)につ いて検討した。

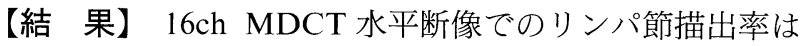
$20.5 \%$, 冠状断像でのリンパ節描出率は $18.5 \%$ であっ. 冠状断像においての短径平均は転移陽性 $7.3 \pm 4.1 \mathrm{~mm}$, 陰 性 4.7士2.0mm で有意差を認めた $(\mathrm{P}<0.05)$. 冠状断像短 径で $5 \mathrm{~mm}$ 以上を転移と診断した場合， sensitivity $64 \%$, specificity 69.1\%, Accuracy 67.7\%であった.

【結 論】食道癌リンパ節転移診断において， $16 \mathrm{ch}$ MDCT $2 \mathrm{~mm}$ 厚冠状断 MPR 像によるリンパ節の短径の 測定が有用であった。

\section{5. 食道癌 (小細胞癌) のリンパ節転移に対し $99 \mathrm{mTc}$} -MDP が集積した一例

吉田 大作, 町田喜久雄, 本田 憲業
高橋 健夫, 奥 真也, 長田 久人
渡部 渉, 大多和伸幸, 岡田 武倫
西村敬一郎, 大野 仁司, 山野 貴史

(埼玉医大総合医療センター)

症例は 54 歳男性. 4ヶ月前より食欲低下, 左腹部痛を 自覚していたが症状の増悪を認めたため, 近医受診した. CT 施行したところ, 鎖骨上窩, 縦隔, 上腹部領域, 腹部傍 大動脈リンパ節に病的腫大を認めた．悪性リンパ腫を疑 われ, 当院受診した. proGRP が 2550 と高值であり,また 内視鏡による生検で病理組織学的に小細胞癌と診断され た. 食道癌 cT3N1M1 stage IVと診断されたため, 化学放 射線療法目的にて当科入院となった，Ga シンチグラ フィー施行したところ, 上記部位に一致して集積を認め た。また，骨転移検索目的に施行した骨シンチグラ フィーにおいても左鎖骨上ならびに上腹部領域に異常集 積を認めた. 治療としては化学療法 (cisplatin, etoposide) を2クール施行した。

99mTc-MDP が食道癌リンパ節転移に集積したきわ
めてまれな一例を経験したので報告する.

\section{6. 食道癌放射線治療における CYFRA21- 1 の臨床的有} 用性

若月

優, 仲本 宗健, 鈴木 良彦

（国立高崎病院放射線科）

【目的】食道癌放射線治療における CYFRA21-1の 臨床的有用性について検討した。

【方 法】1998 年から 2002 年に当科にて放射線治療を 行った食道扁平上皮癌 79 例中 CYFRA を測定した 47 例を対象とした。男性 40 例，女性 7 例，年歯令は中央值 75 歳 (52 93 歳), 病期は I 期 6 例, II期 8 例, III期 16 例, IV 期 16 例であった. 放射線治療は総線量 43Gy〜85Gy (中 央值 70Gy）を行った，治療開始前，終了時にSCC， CYFRA を測定し, 病期, 再発等について検討した.

【結 果】 SCC，CYFRAの陽性率はそれぞれ 51\%， 61.7\%であった. CYFRAの值は病期が進行するに従い 有意に高值となった. IV A 期までの症例での照射野内再 発の割合は治療終了時 SCC 陽性の症例は $2 / 2$ 例, 陰性 化した症例は 4/11 例, CYFRA 陽性の症例は 7/9 例, 陰 性化した症例は $0 / 6$ 例であった。

【結 語】食道癌放射線治療において CYFRA21-1 は 病勢と一致し臨床的に有用である可能性が示唆された。

\section{I 期食道癌に対する放射線治療成績}

石川 仁, 桜井 英幸, 中山 優子
原島 浩一, 山川 通隆, 斉藤 吉弘
岡本 雅彦, 白井 克幸, 原田 耕作
長谷川正俊, 中野 隆史

（群馬大院・医・腫瘍放射線学）

【目 的】I 期食道癌の治療成績・予後因子を検討した. 【方 法】対象は 1986 年から 2002 年までに放射線単独 療法を施行した I 期食道扁平上皮癌 38 例. 性別は男性 30 例, 女性 8 例で, 年齢の中央值は 70 歳 (50〜85 歳) で あった. T因子別では T1a 11 例, T1b 27 例であった. 放 射線治療を施行した理由は手術不能 23 例, 手術拒否 10 例，内視鏡的粘膜切除後の残存 5 例であった. 放射線治 療は外照射単独の場合は 60Gy 以上を投与した. 1991 年 からは原則として T1a および T1b に対して，56Gy およ び 60Gy の外照射施行後に腔内照射を併用した.

【結 果】生存期間の中央值は 41 か月, 5 年粗生存率, 原病生存率はそれぞれ $62 \%, 82 \%$ であった. T 因子別の 5 年原病生存率は T1a で 100\%，T1b では 70\%であった $(\mathrm{p}=0.052)$. 再発は 8 例にみられ, 照射野内再発が 6 例, 遠隔転移が 2 例であり，5 年局所制御率は $86 \%$ であった。 局所再発 6 例中, 4 例が腔内照射非施行例であり, 腔内照 射を施行した 20 例では局所再発は 2 例のみであった。 
腫場長径に関しては $5 \mathrm{~cm}$ 以上の群で 5 年生存率が $64 \%$, $5 \mathrm{~cm}$ 末満の群では $90 \%$ あり有意差が認められた（ $\mathrm{p}=$ $0.020)$.

【結語】I期食道癌に対する放射線単独治療成績は良好 で, 高齢者や合併症の存在する症例に対しても有用で あった。

\section{一般演題(3)}

座長 古田 雅也（獨協医科大学）

\section{8. 放射線治療を試行した左房線維粘液肉腫の一例 原田 耕作, 桜井 英幸, 原島 浩一 松田真里子, 若月 優, 長谷川正俊 中野 隆史 (群馬大院・医・腫瘍放射線学)}

症例は, 44 歳の男性. 1998 年 2 月, 左房粘液腫と診断 され摘出術が施行されたが, 2 年後に局所再発を認めた ため, 腫瘍摘出術と左房部分切除術が施行された. 2001 年, 再び局所再発を認め, 腫場摘出術と内膜欠損部 patch 縫着術が施行された。この時の病理組織学的診断は線維 粘液肉腫であった. 2002 年 5 月, 左肺静脈に浸潤する腫 瘤が認められ, 左肺全摘術が施行されたが, 左房内腫瘤 の再切除は困難と判断された. その後, 左房内腫瘤と左 肺断端部に対し, 総線量 50Gy の外照射が施行された. 腫 瘤の縮小が認められたが，腫瘤は残存した状態であった。 2003 年 8 月ころから呼吸状態が悪化し, 左房内腫瘤の増 大とともに右肺静脈，右房壁への浸潤が認められた。咳 嗽, 喀血と右胸水の貯留が認められたため, 左房腫瘤に 対して外照射を $32 \mathrm{~Gy}$ 施行し, 症状の改善が認められた.

\section{9.肺転移巣にて肺胞出血の所見を来した血管肉腫の 1} 例

\section{斉藤 淳一, 桜井 英幸, 鈴木 義行 \\ 加藤 弘之, 長谷川正俊, 中野 隆史} (群馬大院・医・腫瘍放射線学)

【症 例】症例は 76 歳, 女性. 平成 10 年 8 月, 子宮頸癌 (扁平上皮癌) に対して放射線治療を施行. その後, 当科 外来にて経過観察中であった. 平成 15 年 2 月, 右股関節 痛のため当科再入院となり, 精查の結果, 右大腿骨腫瘍 による病的骨折と診断した。骨折部の生検組織からは転 移性腺癌が疑われた. 入院後の胸部単純写真, CT で, 肺 野にびまん性の斑状, 索状影の出現, およびその急速な 増悪が認められた，画像所見, 気管支鏡検查から肺胞出 血の可能性を考えたが, 病態の原因については不明で あった，臨床検查值から感染症・真菌感染症の存在を考 え, 抗生剤・抗真菌薬による加療を行ったが状態は改善 せず, 大腿骨病的骨折による入院から2ヶ月の経過で死
亡した. 剖検により, 大腿骨腫瘍の組織型は血管肉腫で あり, 肺胞出血の原因は転移巣の肺塞栓に伴う肺胞出血 であったことが判明した．血管肉腫の発生頻度は低く， その転移巣の塞栓に伴う肺胞出血についてはきわめてま れであると考えられるため, 報告する.

\section{I 期 NSCLC に対する三次元放射線治療成績} 河村 英将, 唐澤 克之, 梅澤 朋子 羽生菜穂子 （都立駒込病院放射線科） 新部譲 (北里大学放射線科学)

【目 的】I 期 NSCLC の三次元放射線治療例につい て治療成績を検討した。

【対象・方法】過去 4 年間に, 22 例 (24 病変) に三次元放 射線治療を行った。平均年齢 78.1 歳, 男女比 16/6. 治療 はノンコプラナ固定多門法を用い, 1 回線量 3-4Gy, 平均 総線量 $66.8 \mathrm{~Gy}$, 平均 21.4 分割で平均治療期間は 31.4 日 であった。

【結 果】 全例の 1 年， 3 年粗生存率 $95.4 \%, 82.4 \%, 1$ 年, 3 年局所制御率は $100 \%, 89.3 \%$ であった. 肺の有害事 象は NCI-CTC の grade2 以上が 2 例に認められた。

【結 論】対象のほとんどが高齢者ではあったが生存 率, 局所制御率とも良好な成績であり, 有害事象も許容 範囲内と考元られた，当院で行っている三次元放射線治 療は有効であると考えられる。

\section{一般演題(4)}

座長 仲本 宗健（国立高崎病院）

\section{1. 乳房温存療法後局所皮膚転移をきたし急速な経過を} たどった 1 例

野田 真永, 塩島 和美, 高橋 育 （伊勢崎市民病院放射線科）
根岸 健
(同外科)

【背 景】乳房温存療法後の局所皮虐転移を来たす症例 は早期に遠隔転移を発症し，予後が不良であるとの報告 がある.このような症例は比較的稀であるが, 最近当院 で経験したので報告する.

【症 例】 45 歳女性. 平成 13 年 10 月右乳癌 (硬癌) と 診断され，乳房温存手術を施行された $(\mathrm{Bq}+\mathrm{Ax}$, t2n $1 \alpha \mathrm{M} 0$; stage II B, 切除断端陰性). 術後 25 日目から 右乳房に $50 \mathrm{~Gy} / 25$ 回の放射線治療を施行された。平成 14 年 8 月術創部に再発が認められ, 残存乳房切除につづ き，腫瘍床に $40 \mathrm{~Gy} / 20$ 回の電子線照射を施行された．照 射直後から多発性に右胸皮膚転移, 脳転移を認め, それ ぞれに放射線治療を施行された。平成 15 年 5 月 CT で癌 性髄膜炎が疑われ，急速に意識障害が進行し死亡した。 
再発後の経過は 9ケ月であった.

12. 脳・眼球内に再燃を認めた悪性リンパ腫の 1 例 白井 克幸, 斉藤 淳一, 北本 佳住 長谷川正俊, 中野 隆史

（群馬大院・医・腫瘍放射線学）

症例は 70 歳女性. 右腋窩リンパ節初発の悪性リンパ 腫の診断でCHOP 6 コースを施行され, その 2 年後に視 野障害を認め精査治療を行った. 頭部 MRIで右側頭葉 にまだらに造影される領域を認め, また左視神経にも造 影される領域を指摘されたが, 画像上両側の眼球には明 らかな異常を認めず同部位の細胞診でも異型細胞は認め なかった. 脳内の病変に対しては生検を施行せず, 臨床 経過から悪性りンパ腫の脳・眼球内の再燃と考元た. 今 回の再燃に伴い病理組織学的検討では follicular G III B の可能性も示唆された. 眼科医によるコメントでは眼球 に対して 30Gy 以上の照射は控えた方が良いとの事だっ たが，協議の結果眼球を含めた全脳照射を 40Gy，通常の 全脳室照射を10Gy 行い, 総線量 50Gy 施行した. 照射効 果は画像上で良好ではなかったが, 視力症状は大きく改 善した. 現在は他院血液内科で全身化学療法中である.

\section{3. 濾胞性リンパ腫の組織学的悪性度とガリウムシンチ 所見について}

\section{樋口 啓子, 野中 哲生, 堀越 浩幸 \\ 加藤 弘之, 原口万須美, 玉木 義雄} (群馬県立がんセンター放射線科)

【目 的】濾胞性リンパ腫の組織学的悪性度とガリウム シンチ所見について検討する。

【対象】1994年 1 月-2003 年 12 月に, 当施設で初回 治療を施行した濾胞性リンパ腫 42 例のうち, 組織学的 悪性度と画像評価可能な 25 例を対象とした. 組織学的 悪性度は G1：5例, G2:8例 G3a：6例 G3b：6例 であった。

【結 果】ガリウム集積程度は, 肝と比較して高集積 12 例, 同等 7 例, 低集積 0 例, 集積なし 6 例であった. 肝よ りも高集積あるいは同等の集積を高度, 肝よりも低集積 または集積のないものを軽度とし, 組織悪性度と比較し た。軽度集積は, G1 は 2 例, G2 は 3 例, G3a は 1 例で, G3b は 1 例もなかった.

【結 論】組織学的悪性度の高いものはガリウム集積が 高度である傾向が認められた。

\section{一般演題(5)}

座長 播磨智恵己 (群馬県立がんセンター)

\section{4. 褐色細胞腫におけるクリニカルパスを検討して 浅井佐智江, 蟻川ゆう子, 茂木美由紀 金子由美子}

（群馬大医・附属病院・北 6 階看護室）

樋口 徹也, 粟田さち子

(群馬大院・医・画像核医学)

当院では, 褐色細胞腫に対する 131I-MIBG 治療を昨 年より行っている. 治療は, RI 室という隔離された病棟 で行われる.患者は, 治療に対する不安や隔離病棟での 生活に対するなどにより様及な苦痛を持つ状況にあり, 事前に治療内容・病棟での過ごし方など入院から退院ま での過程を知ることによって不安が軽減されるのではな いかと考える.また，医療者にとっても日々の業務の流 れがわかりやすく, 統一された治療・看護が提供できる と考える.これらのことから, クリニカルパスを作成し たので報告する.

\section{5. 子宮腔内照射クリニカルパスを導入して 井上理英子, 服部政江, 播磨智恵己 橋本 禮子}

(群馬県立がんセンター第 1 病棟)

\section{野中 哲生, 玉木 義雄 (同放射線科) 塚越 照雄 \\ (同放射線課)}

【目 的】子宮頸癌の根治的放射線治療に対し, 低線量 率密封小線源による腔内照射を, 年間約 60 例施行して いる. 治療に関わる看護師は, 腔内照射看護の経験にば らつきがあるため, 対応やケア方法に差異がみられる. そこで看護ケアの統一を図る目的で, 医療者用のクリニ カルパス (以下パス) を導入し, その有用性について検討 し, 若干の示唆を得た.

【対象及び方法】 2003 年 12 月から 2004 年 1 月までに 子宮腔内照射を行った 15 例にパスを使用し, 看護師, 医 師, 放射線技師で検討した.

【結 果】(1)安静度や観察項目をパスに具体的に表示す ることで, 看護師間の差が無く, 安静度の指導や, 適切な 観察ができ，患者の安心感につながったと思われる. (2) 看護師, 医師, 放射線医師の責任が明確になり, 情報の共 有できた，今後も三者で検討の場をもち，より使いやす く改訂を重ねていく必要がある. (4)パスを検討したこと で, 看護判断やケアが不十分な一面がみられた. 具体的 なケア方法を含めた看護マニュアルの見直しをする必要 性があることがわかった。 


\title{
群馬放射線腫瘍研究会 第30回大会記念ミニシンポジウム：
}

\section{放射線腫瘍学と癌患者の診療・看護等における15年間の進歩と今後の課題}

\author{
座長 長谷川正俊 (群馬大学)
}

\section{1. 群馬放射線腫瘍研究会15年間のあゆみ 長谷川正俊（群馬大院・医・腫瘍放射線学）}

昭和 63 年 7 月 2 日に第 1 回群馬放射線腫瘍研究会が 開催されてから 15 年が経過した.この間, 放射線腫瑒学 およびこれに関連する診断, 治療, 技術, 看護, 管理, その 他に目覚しい進歩があったことはいうまでもないが，こ の研究会が各分野において果たしてきた役割も大きい. 今回記念すべき第 30 回大会を開催するにあたり, 各分 野を代表する会員諸氏に協力をお願いして，「放射線腫 瘍学と癌患者の診療・看護等に扔ける 15 年間の進歩と今 後の課題」をテーマとしたミニシンポジウムを企画させ ていただいた。

\section{2. 放射線腫瘍学に関係する画像診断 1 玉木 義雄}

(群馬県立がんセンター放射線科)

$\mathrm{X}$ 線 CT をはじめとする各種画像診断は, 放射線治療 計画をたてる上で必須のモダリティである，そのため， 放射線腫瘍医は各種画像診断にも精通していることが必 要と思われる. 群馬県立がんセンターではこの 10 年間, 放射線腫場学に有用と思われる課題を中心に画像診断に 関する研究を行ってきた。このシンポジウムでは, 最近 の画像診断装置の変遷と,いくつかの研究成果について 報告する. 今後は, biomedical imaging や各種画像の fusion image, MDCTによる3D 画像など放射線嗹瘍学 に応用されることを期待したい。

\section{放射線腫瘍学に関係する画像診断 2}

中山 優子（群馬大院・医・腫瘍放射線学）

\section{一腫瘍 PET一}

群馬大学では, 1984 年にサイクロトロンが設置され, 頭部専用のポジトロン断層検查 (positron emission tomography : PET) が始まり, 1997 年から全身 PET が稼動開 始した，その中でも, FDG-PET は癌の診断に高い精度 を有しており，年間検查件数は 1300 件を超えている. FDG-PET は放射線腫煬学の分野でもきわめて有用で, 正確な病期診断に基づく適応症例の選択・放射線治療計 画・治療効果判定・再発診断・予後予測に用いられてい る.さらに, PET/CT スキャナーの登場により, 精密な放
射線治療計画への寄与が期待されている.

\section{3. 放射線治療・技術 1}

桜井英幸（群馬大院・医・腫瘍放射線学） 放射線治療技術の進歩のキーワードを挙げるとすれ ば, “image-based”と“conformality”と考えられる.すな わち CT シミュレータが広く用いられるようになり, 解 剖学的画像のみならず機能画像までもが治療計画に利用 できるようになったことや, 定位放射線治療, ガンマナ イフ, サイバーナイフ, IMRT, 呼吸同期などの腫瘍に限 局した照射を行う技術が一般に行われるようになった。 小線源治療においても画像の利用により安全な刺入が可 能となり, 最適化された高線量率照射が可能となった。 作業量の増加の中で, 多様な機器やコンピュータにふり まわされずに安全で確実な治療を行うためには, (1)腫瘍 学に精通すること, (2)画像医学に進歩についてゆくこと, そして何よりも(3)ベッドサイドを大切にすることと考え ている.

\section{放射線治療・技術 2 \\ 宮澤 康志}

（群馬大医・附属病院・放射線部）

\section{ーニこ 10 数年の進歩と今後の課題一}

放射線治療に扔けるここ 10 数年の変化は, 各モダリ ティーのディジタル化に基つくくものである.これにより, 多くの画像情報をもとに計画された，高精度な治療パラ メー夕を短時間で生かすことが出来, IMRT のような複 雑な設定を要する照射法が可能になった。一方放射線治 療の有効性が広く認められ, 患者数は増加しつづけてい る. 反面誤照射事故が複数件報じられ，放射線治療業務 のあり方, 治療担当放射線技師の数や熟練度についても 検討すべき施設は少なくないと考える. 各関連学会にお いても誤照射事故防止に関する検討が行われているが, これといった方策が示されていないのが実情である.

高精度な治療システムを十分活用するためには各種の 基本的項目について検討なされなければならないが, 今 回はこれらの中から, 線量照射照準を中心に述べてみた い. 


\section{放射線治療・技術 3 \\ 加藤 真吾（放医研重粒子医科学センター） 一粒子線治療一}

陽子線や重イオン線などの荷電粒子線は, その線量分 布上ブラッグピーク (Bragg peak) があるため, 病巣が重 要臓器に接していても選択的な照射が可能である. また 重イオン線は高 LET 放射線であるため, 光子線や陽子 線よりも放射線損傷は回復しにくく, 酸素効果の影響は 少なく, 細胞周期の影響を受けにくいなどの生物学的な 特長を有している.このため放射線抵抗性の難治性の腫 瘍に対しても効果が期待される. 放医研では重イオン線 の一つである炭素イオン線による治療の臨床試験を 1994 年から行い, 2003 年 8 月までに 1600 名を超える症 例が登録し，その安全性と有効性を確認してきた。この 結果を受けて 2003 年 11 月末からは高度先進医療の認可 のもとに治療を行っている.今後は全国への普及を目指 して機器・設備の軽量化が検討されている.

\section{4. 化学放射線療法 \\ 高橋 健夫}

(埼玉医大総合医療センター放射線科)

放射線治療の進歩により藏器の機能・形態温存をはか りつつ癌を治癒させる可能性が高まっている. 比較的早 期の腫瘍や限局性腫瘍では定位照射などの技術により局 所制御率が手術に匹敵するまでに向上している.しかし 進行性癌に対しては依然として課題が多い. 化学放射線 療法は頭頸部癌や肺癌で有用性が明らかとなり, 多くの 進行癌で標準治療となりつつある. 特に近年注目を集め ているのが食道癌である. 手術不能な病期のみならず手 術可能症例に対しても有用性が指摘され今後の検討がま たれる.化学放射線療法は放射線と抗がん剤の併用によ る局所制御の向上と照射野外の潜在的遠隔転移の制御が 目的となる．照射技術の進歩とともに腫瘍に選択的に増 感効果を求める工夫も今後求められるであろう.

\section{放射線治療と分子標的治療}

\section{秋元 哲夫（群馬大院・医・腫瘍放射線学）}

様々な分子を標的にした分子標的治療が開発されてい る. 癌の増殖を抑制するシグナル伝達や血管新生の制御 分子を標的にした薬剤もあり, 標的分子の中には細胞の 放射線応答に関わる分子も少ない。このような観点から， 放射線治療と分子標的治療薬の併用は将来的に有望な治 療となりうる可能性があり, その基礎研究が進行してい る. 多くの分子標的治療薬は単独でも臨床試験の段階で あるが，放射線治療との併用の臨床試験に進んでいる薬 剂もある. 今後の臨床応用を目指して, 放射線増感の可 能性のある分子標的治療薬あるいは分子標的を明らかに
する基礎研究は重要であるため, 放射線増感を目指した 分子標的の研究と臨床の現状について簡単に概説する.

\section{5. 放射線治療と緩和治医療 塩島 和美, 高橋 育}

（伊勢崎市民病院放射線科）

放射線腫瘍研究会の 15 年のあゆみに沿った緩和ケア の動向について以下の項目を挙げ考察を述べる．1. 緩和 医療に対する社会的な関心が高まっていることから，ケ アを担うものは豊富な経験と謙虚な姿勢が必要とされて きている. 2. 病院機能の分化により緩和ケアを行う場が 多様化していることから,一般病院の主治医としては地 域連携や訪問看護などを有効に活用できる機転と熱意が 必要とされる. 3. 緩和ケア内部で専門化が進んでいるこ とから腫瘍専門医といえども片手間では緩和ケアを行え ない状況になりつつある.

\section{6. 看護・危機管理 細野美代子}

（群馬大医・附属病院・北 6 階看護室）

\section{一放射線科の15年のあゆみ一}

群馬大学医学部附属病院放射線科では，この 15 年間 に建物・病棟, スタッフ, 看護師等が変動したが, さらに 業務内容にも大きな変化があった. 特に, クリニカルパ スの導入, 診療記録の統一化・IT 化, 合同ケースカンファ レンスの定期開催等は現在重要な役割を果たしている. 危機管理面では, 病院レベルの安全対策管理委員会・危 機管理委員会が発足し，どんな事故でもインシデントレ ポート,アクシデントレポートを作成して, 対策を検討 するようになったが，当科ではさらに病棟レベルの危機 管理委員会を定期的に開催し，インシデントレポートの 分析や改善方法の話し合い, 診療についての意見交流を 行なっている. 特に注射点滴薬のワゴン制とチェック体 制は, 病院レベルおよび病棟レベルでの厳重なチェック 機構であり，多少手間を要すが，注射関連のミスは著し く減少している.

\section{特別講演}

座長 中野 隆史 (群馬大学)

\section{「これからの日本の医療と放射線治療」 新部 英男 \\ (群馬大学医学部放射線医学講座前教授)}

